\title{
Modelling acidification, recovery and target loads for headwater catchments in Nova Scotia, Canada
}

\author{
C. J. Whitfield ${ }^{1}$, J. Aherne ${ }^{2}$, P. J. Dillon ${ }^{2}$, and S. A. Watmough ${ }^{2}$ \\ ${ }^{1}$ Watershed Ecosystems, Trent University, Peterborough, Ontario, Canada \\ ${ }^{2}$ Environment and Resource Studies, Trent University, Peterborough, Ontario, Canada
}

Received: 18 September 2006 - Published in Hydrol. Earth Syst. Sci. Discuss.: 29 November 2006

Revised: 30 January 2007 - Accepted: 22 February 2007 - Published: 2 March 2007

\begin{abstract}
The response of twenty acid-sensitive headwater catchments in Nova Scotia to acidic deposition was investigated for the period 1850-2100 using a dynamic hydrochemical model (MAGIC: Model of Acidification of Groundwater in Catchments). To ensure robust model simulation, MAGIC was calibrated to the long-term chemical trend in annual lake observations (13-20 years). Model simulations indicated that the surface waters of all twenty catchments acidified to the 1970s but showed subsequent recovery (increases in acid neutralising capacity (ANC) and $\mathrm{pH}$ ) as sulphate deposition decreased. However, under proposed future emissions reductions (approximately $50 \%$ of current deposition) simulated $\mathrm{ANC}$ and $\mathrm{pH}$ will not return to estimated pre-industrial levels by 2100 . An ANC of $20 \mu \mathrm{mol}_{\mathrm{c}} \mathrm{L}^{-1}$ and $\mathrm{pH}$ of 5.4 were defined as acceptable chemical thresholds (or critical chemical limits) for aquatic organisms in the current study. Under the proposed emissions reductions only one catchment is predicted to remain below the critical limit for ANC by 2100; three additional catchments are predicted to remain below the critical limit for $\mathrm{pH}$. Dynamic models may be used to estimate target loads, i.e., the required deposition reductions to achieve recovery within a given time. Setting target loads at approximately $30 \%$ of current depositions would allow three of the four lakes to reach the chemical criteria by 2030 . In contrast to the generally good prognosis for surface waters, soils lost an average of $32 \%$ of estimated initial base saturation and recovery is estimated to be very slow, averaging $23 \%$ lower than pre-acidification levels in 2100 .
\end{abstract}

Correspondence to: C. J. Whitfield

(cwhitfield@trentu.ca)

\section{Introduction}

In eastern Canada the acidification of surface waters was recognized as early as the 1950s (Gorham 1957); however, atmospheric deposition of anthropogenically derived sulphur (S) only began to cause concern during the 1970s and 1980s when the loss of fish populations from acidified waters was recorded in Ontario (Beamish and Harvey, 1972) and acidification was recognized as widespread (Dillon et al., 1978). In Nova Scotia, which is downwind of major North American emission sources, an estimated $90 \%$ of atmospheric acidic deposition results from long range transboundary air pollution (Shaw, 1979). Environment Canada began monitoring lake chemistry in Nova Scotia in the early 1980s. These lakes $(n=72)$ have been particularly important for documenting the impacts of changing acid deposition levels on surface waters in Nova Scotia, which owing largely to the presence of shallow base-poor soils, has been identified as the most acidsensitive province in Atlantic Canada (Clair et al., 2003).

In the mid-1980s, efforts to combat the acidification of terrestrial and aquatic ecosystems through pollution abatement measures were introduced in North America, e.g., the Canadian Acid Rain Control Program (1985) and the CanadaU.S. Air Quality Agreement (AQA, 1991). These programs were designed to reduce emissions of sulphuric acid precursors to the atmosphere; as a consequence, sulphate $\left(\mathrm{SO}_{4}{ }^{2-}\right)$ deposition in Canada has decreased over the last two decades (Dillon et al., 1988; Dillon et al., 2003; Jeffries et al., 2003). Surface waters in eastern Canada have responded to decreased $\mathrm{SO}_{4}{ }^{2-}$ deposition through improvements in water quality, including substantial decreases in $\mathrm{SO}_{4}{ }^{2-}$ concentrations and small improvements in acid neutralizing capacity (ANC) and pH (Dillon et al., 2003; Jeffries et al., 2003). In Nova Scotia, limited improvements in water chemistry have been observed (Clair et al., 2002). Despite decreasing concentrations of $\mathrm{SO}_{4}{ }^{2-}$ and $\mathrm{H}^{+}$in deposition and corresponding decreases in lake concentrations of $\mathrm{SO}_{4}{ }^{2-}$, Whitfield et

Published by Copernicus GmbH on behalf of the European Geosciences Union. 


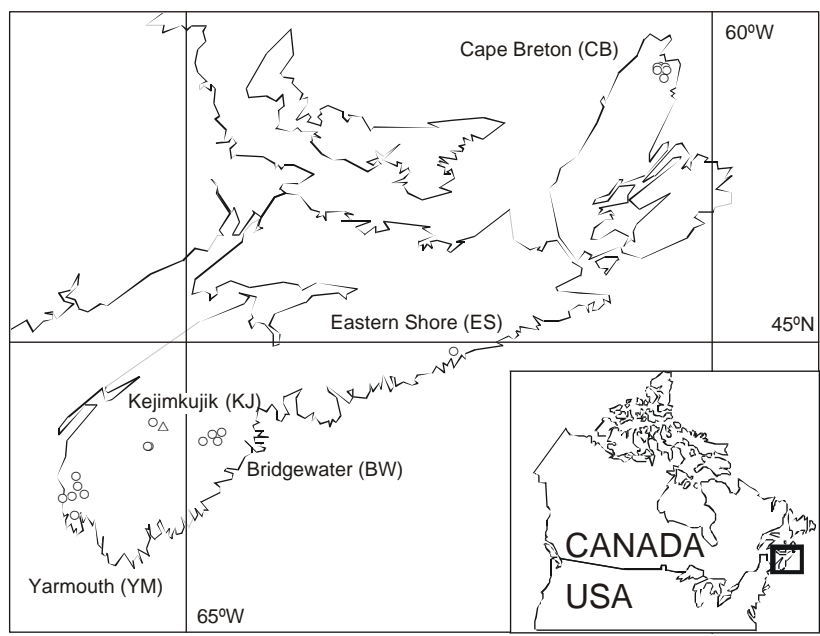

Fig. 1. Location of the 20 acid-sensitive study lakes (open circles) in five regions and the Canadian Air and Precipitation Monitoring Network deposition station at Kejimkujik (open triangle) in Nova Scotia.

al. (2006a) did not detect responses for $\mathrm{H}^{+}$and alkalinity in lakes.

In Canada, few long-term water quality data sets exist, and none are long enough to capture the entire acidification process (Dillon et al., 1987). Steady-state models can be used to estimate equilibrium conditions for an ecosystem and provide useful insights as to what changes can be expected in the future. However, many ecosystems are not in equilibrium with present or projected depositions, since there are buffer mechanisms that delay the reaching of a steady-state for years, decades or even centuries. Dynamic models attempt to estimate the time required for a new equilibrium to be achieved, or more applicably, they provide an estimate of the future soil or surface water chemistry in response to deposition changes resulting from planned emission reductions. Dynamic models can also be used to predict the likely benefits from costly reductions in acid emissions, which is an extremely important consideration for policy makers.

There is increasing recognition of the importance of dynamic models in developing emission reduction policies. The Model of Acidification of Groundwater in Catchments (MAGIC: Cosby et al., 1985a; Cosby et al., 2001) has recently been applied in eastern Canada to assess the impact of proposed sulphur emission reductions (e.g., Aherne et al., 2003; Clair et al., 2003; Larssen et al., 2003; Aherne et al., 2004; Clair et al., 2004). The use of dynamic models will likely increase in the near future as the efficacy of current emission regulations are evaluated in Canada. MAGIC has been in use for 20 years and is one of the most widely used soil-chemical acidification models. MAGIC has proven to be a useful tool for simulating water acidification responses at the catchment (Cosby et al., 1985b; Cosby et al., 1996) and regional (Aherne et al., 2003; Wright et al., 2005) scale.
In the current study, MAGIC was applied to twenty acidsensitive headwater catchments in Nova Scotia to characterize changes in surface water and soil chemistry since industrialization activities began in eastern North America. Future sulphur (S) and nitrogen $(\mathrm{N})$ emissions are based on Canada's post-2000 Acid Rain Strategy and the proposed Clear Skies Legislation in the United States (Environment Canada, 2004; WxPrime, 2004). The twenty study lakes and their catchments, which are a subset of the 72 lakes monitored by Environment Canada, have been studied for trends in lake chemistry and steady-state critical loads for lakes (Whitfield et al., 2006a) while five of the catchments underwent critical evaluation of mineral weathering rates and critical loads for forest soils (Whitfield et al., 2006b). Recent model simulations of Nova Scotian surface waters suggest that limited recovery will take place given the current deposition forecasts (Clair et al., 2003), with base cation concentrations being particularly slow to recover (Clair et al., 2004).

Unlike previous modelling studies, detailed site-measured soil data are used as model inputs for each catchment. In addition, MAGIC was calibrated to the long-term trend in observed data rather than a multi-year average to more accurately characterize the trend through the calibration period.

\section{Methods}

\subsection{Study area}

The province of Nova Scotia is located on Canada's Atlantic Coast and experiences a humid continental climate, while the marine waters that surround the province moderate against extreme air temperatures in summer and winter. Annual rainfall in Nova Scotia averages approximately $1.40 \mathrm{~m}$, ranging from $1.36 \mathrm{~m}$ in the south to $1.51 \mathrm{~m}$ at the Eastern Shore. Nonmarine $\mathrm{S}$ and $\mathrm{N}$ deposition in Nova Scotia currently averages $66 \mathrm{mmol}_{\mathrm{c}} \mathrm{m}^{-2} \mathrm{yr}^{-1}$, and is composed of approximately equal portions of sulphur (as $\mathrm{SO}_{4}{ }^{2-}$ ) and nitrogen (as nitrate $\left(\mathrm{NO}_{3}{ }^{-}\right)$and ammonium $\left(\mathrm{NH}_{4}{ }^{+}\right)$). Soils are poorly developed podzols deposited during glacial retreat (16000 years before present; Clair et al., 2003) and are sandy and shallow. Precambrian geology is typical across the province; quartz, $\mathrm{K}$-feldspar, and plagioclase dominate soil mineralogy (Whitfield et al., 2006b) with the major underlying bedrock being Ordovician slates and Devonian-Carboniferous granites.

Twenty headwater lakes in Nova Scotia, located in five geographic regions (Cape Breton, Bridgewater, Eastern Shore, Kejimkujik, Yarmouth) were selected for study from the 72 acid-sensitive lakes monitored under the Environment Canada Atlantic Region temporal monitoring network (Fig. 1). Catchments were selected to include lakes with a range of alkalinity, dissolved organic carbon (DOC), and $\mathrm{pH}$ values, so as to capture varying levels of acid-sensitivity (Table 1). All of the catchments are small, primarily forested and were selected to maintain consistency in hydrologic or- 
Table 1. Lake area and five year (1998-2002) annual averages lake concentrations for pH, major ions, Gran alkalinity (ALK), and dissolved organic carbon (DOC). See Fig. 1 for catchment location.

\begin{tabular}{|c|c|c|c|c|c|c|c|c|c|c|}
\hline $\begin{array}{l}\text { Catchment } \\
\text { (Region) }\end{array}$ & $\begin{array}{c}\text { Lake area } \\
\text { ha }\end{array}$ & $\mathrm{pH}$ & $\begin{array}{c}\mathrm{Ca}^{2+} \\
\mu \mathrm{mol}_{\mathrm{c}} \mathrm{L}^{-1}\end{array}$ & $\begin{array}{c}\mathrm{Mg}^{2+} \\
\mu \mathrm{mol}_{\mathrm{c}} \mathrm{L}^{-1}\end{array}$ & $\begin{array}{c}\mathrm{Na}^{+} \\
\mu \mathrm{mol}_{\mathrm{c}} \mathrm{L}^{-1}\end{array}$ & $\begin{array}{c}\mathrm{K}^{+} \\
\mu \mathrm{mol}_{\mathrm{c}} \mathrm{L}^{-1}\end{array}$ & $\begin{array}{c}\mathrm{SO}_{4}{ }^{2-} \\
\mu \mathrm{mol}_{\mathrm{c}} \mathrm{L}^{-1}\end{array}$ & $\begin{array}{c}\mathrm{Cl}^{-} \\
\mu \mathrm{mol}_{\mathrm{c}} \mathrm{L}^{-1}\end{array}$ & $\begin{array}{c}\mathrm{ALK} \\
\mu \mathrm{mol}_{\mathrm{c}} \mathrm{L}^{-1}\end{array}$ & $\begin{array}{c}\mathrm{DOC} \\
\mathrm{mg} \mathrm{L}^{-1}\end{array}$ \\
\hline Allens $(\mathrm{YM})^{\mathrm{a}}$ & 93.0 & 5.93 & 48 & 109 & 531 & 22 & 44 & 611 & 99.1 & 5.2 \\
\hline $\operatorname{Bird}(\mathrm{YM})$ & 30.0 & 6.62 & 28 & 34 & 211 & 11 & 36 & 231 & 84.5 & 2.7 \\
\hline Brenton (YM) & 58.4 & 4.90 & 77 & 78 & 323 & 13 & 83 & 340 & 20.2 & 17.5 \\
\hline Jesse (YM) & 26.8 & 6.19 & 67 & 86 & 236 & 15 & 64 & 277 & 41.6 & 4.8 \\
\hline Tedford (YM) & 81.6 & 6.32 & 75 & 79 & 329 & 12 & 74 & 365 & 50.0 & 2.8 \\
\hline Trefry (YM) & 29.6 & 6.42 & 94 & 104 & 302 & 14 & 84 & 325 & 86.7 & 5.9 \\
\hline Pebbleloggitch (KJ) & 33.4 & 4.50 & 16 & 27 & 113 & 5 & 41 & 105 & -31.8 & 10.8 \\
\hline Annis (BW) & 87.0 & 6.65 & 81 & 55 & 117 & 6 & 53 & 125 & 66.6 & 1.6 \\
\hline Huey (BW) & 13.3 & 5.76 & 42 & 35 & 126 & 2 & 50 & 120 & 10.9 & 3.6 \\
\hline Little Wiles (BW) & 36.3 & 5.24 & 51 & 52 & 120 & 6 & 100 & 119 & 22.3 & 2.1 \\
\hline Matthew (BW) & 16.9 & 5.70 & 60 & 61 & 245 & 11 & 67 & 249 & -2.5 & 7.0 \\
\hline Halfway (ES) & 106.6 & 5.46 & 46 & 34 & 127 & 5 & 48 & 126 & 8.2 & 5.0 \\
\hline Mica Hill (CB) & 5.0 & 5.27 & 59 & 36 & 159 & 8 & 37 & 146 & 61.3 & 9.8 \\
\hline Round (CB) & 14.4 & 5.13 & 29 & 34 & 144 & 7 & 32 & 133 & 0.9 & 8.1 \\
\hline
\end{tabular}

a Data reported is for 2004. Nitrate and ammonium were below detection limits and are not reported here. Region: YM = Yarmouth, $\mathrm{KJ}=$ Kejimkujik, BW = Bridgewater, ES = Eastern Shore and CB = Cape Breton.

der and size (maximum area of $\left.6 \mathrm{~km}^{2}\right)$. Due to the close proximity of the catchments to the ocean $(<50 \mathrm{~km})$, deposition and lake chemistry demonstrate a strong marine influence.

\subsection{Model description}

MAGIC (Cosby et al., 1985a) is a process-oriented lumped parameter model of intermediate complexity. MAGIC was developed for the purpose of quantifying the long-term ecosystem response to acidic deposition at the catchment scale. The model is used to simulate average annual or monthly soil solution and surface water concentrations for $\mathrm{SO}_{4}{ }^{2-}$, calcium $\left(\mathrm{Ca}^{2+}\right)$, magnesium $\left(\mathrm{Mg}^{2+}\right)$, sodium $\left(\mathrm{Na}^{+}\right)$, potassium $\left(\mathrm{K}^{+}\right)$and $\mathrm{pH}$, as well as exchangeable soil fractions of $\mathrm{Ca}^{2+}, \mathrm{Mg}^{2+}, \mathrm{Na}^{+}$and $\mathrm{K}^{+}$. The model can be used to represent aggregated uniform soil compartments and a surface water compartment (lake or stream). The latest version of the model (7.77: Cosby et al., 2001) was used in the current study.

MAGIC includes short-term processes described by equilibrium reactions that regulate ionic balance, and long-term input-output processes that control the catchment mass balance. These processes include weathering of minerals, adsorption and exchange of base cations and aluminium by soils, anion retention by soils, buffering of soil solution $\mathrm{pH}$ by weak organic and inorganic acids and biologically mediated uptake of cations and anions. The equilibrium equations are represented by inorganic aluminium reactions for surface and soil water, cation exchange reactions, and inorganic carbon equations that describe the chemical change that occurs as soil water enters the stream channel. Ionic balance is governed by a single equation, and rates of change for each ion in soil water and surface water are calculated through the mass balance equations. Collectively, the mass balance equations describe the input-output relationships for base cations and strong acid anions. A triprotic $\mathrm{pH}$ model is included for modelling soil and surface water organic acidity. Additional details describing the model structure are available in Cosby et al. (1985a) and Cosby et al. (2001).

\subsection{Lake data}

Surface water chemistry data collection started in 1983 for nine of the lakes and in 1990 for the remaining eleven. All of the study lakes were monitored through to 2002, with the exception of Allens Lake, where monitoring ceased in 1989. Samples were collected at mid-lake with a maximum frequency of twice per year (spring turnover or spring and fall turnover). Samples were analyzed for specific conductance, DOC, alkalinity, $\mathrm{pH}, \mathrm{NO}_{3}{ }^{-}$, total $\mathrm{N}, \mathrm{SO}_{4}{ }^{2-}$, chloride $\left(\mathrm{Cl}^{-}\right)$, $\mathrm{Na}^{+}, \mathrm{Mg}^{2+}, \mathrm{K}^{+}, \mathrm{Ca}^{2+}$, and total aluminium at Environment Canada's Analytical Laboratory in Moncton (see Table 1). A description of the analytical methods is available in Clair et al. (2001). Data quality was evaluated by using ion balance, with $+/-10 \%$ set as the criterion for acceptance. 


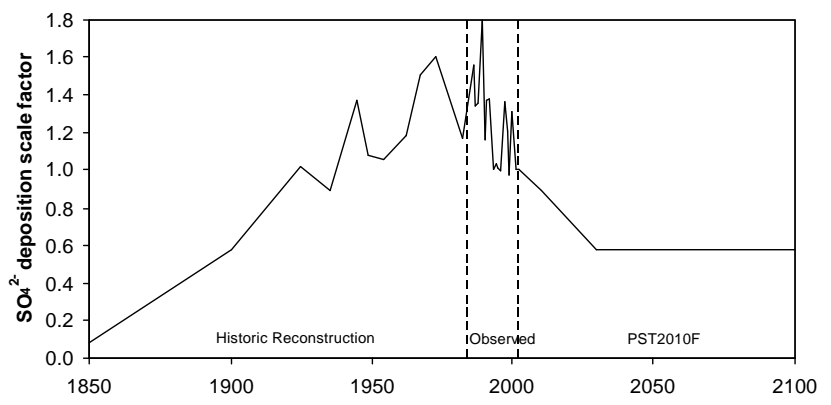

Fig. 2. Estimated sulphate deposition scale factors (relative to 2002) for the period 1850-2100. Broken lines separate the deposition scenario into three time periods originating from different data sources: historical (based on emissions inventories), observed (Kejimkujik CAPMoN station data) and forecast (from PST2010F deposition scenario).

\subsection{Soil data}

Soils were collected from each soil horizon at multiple pits (6-12) in each catchment during 2003 or 2004. Depths of each horizon were recorded in the field. Soils were analyzed in the laboratory for $\mathrm{pH}$, bulk density, loss on ignition, cation exchange capacity (CEC) and exchangeable base cation saturation (BS). CEC and BS were depth and density weighted. Detailed methods concerning soil collection and analysis are presented in Whitfield et al. (2006b). Soil horizon data were amalgamated (or lumped) into a single layer, which was deemed reasonable given the shallow soil depth across the study area (Table 2).

\subsection{Deposition data}

Daily precipitation chemistry (1984-2002) including $\mathrm{pH}$, $\mathrm{Cl}^{-}, \mathrm{SO}_{4}{ }^{2-}, \mathrm{NO}_{3}{ }^{-}, \mathrm{NH}_{4}{ }^{+}, \mathrm{Ca}^{2+}, \mathrm{Mg}^{2+}, \mathrm{Na}^{+}$, and $\mathrm{K}^{+}$ was monitored through 24-hour integrated samples collected with a wet only precipitation collector at the Canadian Air and Precipitation Monitoring Network (CAPMoN) station in Kejimkujik National Park (see Fig. 1). Daily precipitation was measured using a type B rain gauge and a Nipher shielded snow gauge. Regional wet deposition maps for the period 1994-1998 for all major ions in precipitation were provided by Environment Canada at a resolution of approximately $45 \times 45 \mathrm{~km}$ (Ro and Vet, 2003). Dry deposition inputs to mixed land cover for all major ions at a resolution of approximately $35 \times 35 \mathrm{~km}$ (Vet and Shaw, 2004) were interpolated with the wet deposition field to a common grid resolution $(25 \times 25 \mathrm{~km})$ and combined to produce consistent regional coverages for deposition. Using these data to define the spatial pattern of deposition across the study region, scale factors were established between all grids and the Kejimkujik grid (grid containing the Kejimkujik CAPMoN station). Time-series of deposition (1984-2002) were generated for each catchment using the observed temporal trend at the Ke- jimkujik station and the grid-specific scale factors, assuming that the factors remained constant over time.

Deposition hindcast sequences (1850-2002) were generated for $\mathrm{SO}_{4}{ }^{2-}, \mathrm{NO}_{3}{ }^{-}, \mathrm{NH}_{4}{ }^{+}$, and base cations $\left(\mathrm{Ca}^{2+}\right.$, $\mathrm{Mg}^{2+}, \mathrm{Na}^{+}$and $\mathrm{K}^{+}$) and scaled to present day deposition. Sulphate deposition history was generated from historic $\mathrm{S}$ emissions inventories using data from two sources (18501940: Office of Technology Assessment, 1984; 1940-2000: U.S. EPA, 2000). These data were used to create deposition scale factors relative to the present deposition level (1984-2002) for the period of model simulation (Fig. 2). The $\mathrm{NO}_{3}{ }^{-}$hindcast was similarly generated (1900-1980: Husar, 1994; 1980-2000: Galloway et al., 1996). The hindcast for $\mathrm{NH}_{4}{ }^{+}$was constructed using global ammonia $\left(\mathrm{NH}_{3}\right)$ emissions for the period 1900-1950 (Galloway, 1995) and using $\mathrm{NH}_{3}$ emissions in the U.S. for the period 1950-2000 (Galloway et al., 1996). As the 1900 estimates of $\mathrm{NO}_{3}{ }^{-}$and $\mathrm{NH}_{3}$ emissions were very low, and prior emissions estimates are not available, the levels for 1900 were assumed to reflect background levels. Increases in base cation deposition were set to proportionally reflect the documented increases for $\mathrm{SO}_{4}{ }^{2-}$ deposition. This assumption seems reasonable as increased industrial activity has led to increased atmospheric deposition of base cations, largely through fossil fuel combustion (e.g., Hedin, 1994). The background levels of base cation deposition were estimated from potential acidity (Aherne and Farrell, 2002) assuming precipitation of $\mathrm{pH}$ prior to industrialization approaches the $\mathrm{pH}$ of pure rainwater (5.6):

$$
\begin{aligned}
& \text { Potential acidity }= \\
& \quad \text { non-marine }\left(\mathrm{SO}_{4}^{2-}\right)+\mathrm{NO}_{3}^{-}+\mathrm{NH}_{4}^{+-} \\
& \text {non-marine }\left(\mathrm{Ca}^{2+}+\mathrm{Mg}^{2+}+\mathrm{K}^{+}\right)
\end{aligned}
$$

Future $\mathrm{SO}_{4}{ }^{2-}$ deposition was derived from recent emission scenarios for eastern Canada (PST2010F: WxPrime, 2004; Environment Canada, 2004) based on proposed reductions under the United States' Clear Skies Legislation, and Canada's Post-2000 Acid Rain Strategy. Under this scenario, the change in emissions is expected to yield 2030 non-marine $\mathrm{SO}_{4}{ }^{2-}$ deposition slightly higher than $50 \%$ of 2000 levels. Deposition was assumed to decrease linearly from current day until 2030 and remain constant thereafter (Fig. 2). Future $\mathrm{NO}_{3}{ }^{-}$emission scenarios also exist for eastern Canada (see NOX3P: WxPrime, 2004); however, $\mathrm{NO}_{3}{ }^{-}$and $\mathrm{NH}_{4}{ }^{+}$ deposition were set at current levels for the duration of the forecast period. In the current study, $\% \mathrm{~N}$ retention in the study catchment was assumed to remain constant as inorganic $\mathrm{N}$ is almost quantitatively retained in the catchments $\left(\mathrm{NH}_{4}{ }^{+}\right.$and $\mathrm{NO}_{3}{ }^{-}$lake concentrations are below detection limits). As such, future changes in $\mathrm{N}$ deposition will have little influence on the simulation results. Base cation deposition forecast scenarios were scaled to the $\mathrm{SO}_{4}{ }^{2-}$ trend according to the same relationship used for the hindcast. All other ion deposition sequences were set constant at current deposition levels throughout the forecast period. 
Table 2. Fixed catchment-specific lake and soil input parameters for MAGIC for each study site.

\begin{tabular}{|c|c|c|c|c|c|c|c|c|c|c|c|}
\hline \multirow[t]{2}{*}{ Catchment } & \multicolumn{5}{|c|}{ Lake Parameters } & \multicolumn{6}{|c|}{ Soil Parameters } \\
\hline & $\begin{array}{l}\text { Precip } \\
\text { m }\end{array}$ & $\begin{array}{c}\text { Runoff } \\
\mathrm{m}\end{array}$ & $\begin{array}{c}\text { Catchment Area } \\
\text { ha }\end{array}$ & $\begin{array}{c}\text { Relative Area } \\
\%\end{array}$ & $\begin{array}{l}\text { Retention Time } \\
\text { years }\end{array}$ & $\begin{array}{l}\text { Depth } \\
\text { m }\end{array}$ & $\begin{array}{c}\text { Porosity } \\
\%\end{array}$ & $\begin{array}{l}\text { Bulk Density } \\
\mathrm{kg} \mathrm{m}^{-3}\end{array}$ & $\begin{array}{l}\mathrm{BS} \\
\%\end{array}$ & $\begin{array}{c}\mathrm{CEC} \\
\mathrm{mmol}_{\mathrm{c}} \mathrm{kg}^{-1}\end{array}$ & $\mathrm{pH}$ \\
\hline Bird & 1.38 & 0.98 & 120 & 25 & 0.51 & 0.46 & 0.59 & 843 & 9.1 & 80 & 4.88 \\
\hline Brenton & 1.38 & 0.98 & 495 & 11.8 & 0.14 & 0.32 & 0.66 & 570 & 11.0 & 111 & 4.44 \\
\hline Jesse & 1.38 & 0.98 & 185 & 14.5 & 0.35 & 0.37 & 0.69 & 605 & 12.5 & 83 & 4.45 \\
\hline Tedford & 1.36 & 0.97 & 245 & 33.3 & 0.43 & 0.33 & 0.70 & 537 & 6.8 & 136 & 4.52 \\
\hline Big Dam East & 1.39 & 1.00 & 200 & 22.8 & 0.00 & 0.42 & 0.73 & 256 & 14.4 & 89 & 5.17 \\
\hline Pebbleloggitch & 1.39 & 1.00 & 160 & 20.9 & 0.30 & 0.49 & 0.67 & 512 & 18.1 & 53 & 5.03 \\
\hline Annis & 1.43 & 1.05 & 215 & 40.5 & 2.50 & 0.34 & 0.66 & 695 & 12.2 & 67 & 5.23 \\
\hline Huey & 1.43 & 1.05 & 262 & 5.1 & 0.03 & 0.53 & 0.66 & 634 & 9.0 & 78 & 5.08 \\
\hline Little Wiles & 1.44 & 1.05 & 313 & 11.6 & 0.10 & 0.34 & 0.63 & 667 & 7.3 & 126 & 4.70 \\
\hline Matthew & 1.43 & 1.05 & 259 & 6.5 & 0.22 & 0.47 & 0.59 & 811 & 10.8 & 77 & 4.73 \\
\hline Long & 1.44 & 1.06 & 505 & 1.3 & 0.01 & 0.41 & 0.76 & 422 & 17.3 & 106 & 4.54 \\
\hline Mica Hill & 1.44 & 1.06 & 268 & 1.9 & 0.04 & 0.32 & 0.61 & 490 & 17.2 & 75 & 4.25 \\
\hline Round & 1.44 & 1.06 & 370 & 3.9 & 0.04 & 0.28 & 0.51 & 846 & 20.6 & 58 & 4.29 \\
\hline
\end{tabular}

Precip $=$ precipitation, $\mathrm{BS}=$ Base Saturation, $\mathrm{CEC}=$ cation exchange capacity.

\subsection{Model parameters and calibration}

Most of the required model input parameters were derived from site measurements of the physical and chemical properties for the study catchments (Table 2). For a number of parameters including temperature, partial pressure of carbon dioxide and dissociation constants for DOC, site data were not available and regional default values were used across the study catchments (Table 3). Time-series of annual atmospheric deposition (wet plus dry) at each study catchment were used to calibrate to a multiple year period (1984-2002). Deposition included all major ions: $\mathrm{Ca}^{2+}, \mathrm{Mg}^{2+}, \mathrm{Na}^{+}, \mathrm{K}^{+}$, $\mathrm{NH}_{4}{ }^{+}, \mathrm{NO}_{3}{ }^{-}, \mathrm{SO}_{4}{ }^{2-}$ and $\mathrm{Cl}^{-}$. Calibration to a single point (e.g., typically a five-year average) is less constrained and could potentially result in discrepancies in hindcast and forecast simulations. The use of multiple calibration points ensures a better fit to the long-term behaviour of the calibrated parameter, allowing for a more robust calibration. Water balance was described by precipitation and runoff, with $100 \%$ of flow to the lake routed through one (aggregated) soil layer; flow routing was constant over time. Long-term means for runoff were taken from regional maps (Table 2; Environment Canada, 1978).

MAGIC includes a triprotic $\mathrm{pH}$ model used to model soil and surface water organic acidity. Three sets of parameters (Adirondack lakes, Driscoll et al., 1994; Swedish boreal lakes and Czech temperate lakes, Hruska et al., 2003) for the triprotic $\mathrm{pH}$ model were assessed for their suitability to the study region. Using $\mathrm{pH}$ and DOC concentrations,
Table 3. Regional default input parameters for MAGIC applied to all study catchments.

\begin{tabular}{lccc}
\hline Parameter & Units & Soil & Lake \\
\hline Sulphate adsorption half saturation & $\mathrm{mmol}_{\mathrm{c}} \mathrm{m}^{-3}$ & 100 & - \\
Sulphate adsorption maximum capacity & $\mathrm{mmol}_{\mathrm{c}} \mathrm{kg}^{-1}$ & 0.1 & - \\
Aluminum solubility constant & $\log _{10}$ & 9 & 7.5 \\
Temperature & ${ }^{\circ} \mathrm{C}$ & 7.5 & 7.5 \\
Partial Pressure of $\mathrm{CO}_{2}$ & $\%$ atm & 0.55 & 0.15 \\
pK1 DOC & $-\log _{10}$ & 2.5 & 2.5 \\
pK2 DOC & $-\log _{10}$ & 4.42 & 4.42 \\
pK3 DOC & $-\log _{10}$ & 6.7 & 6.7 \\
\hline
\end{tabular}

the organic charge predicted by the triprotic model for each lake was plotted against the observed anion charge deficit (calculated through charge balance and assumed to reflect organic charge). The parameters for the triprotic model presented by Hruska et al. (2003) for lakes in the Czech Republic produced the best agreement between observed and simulated values $\left(\mathrm{R}^{2}=0.96\right)$ and were used in the current study (Table 3 ). Charge density calibrated with this model were lower than those reported by Hruska et al. (2003) (mean: $2.9 \mu \mathrm{mol}_{\mathrm{c}} \mathrm{mg}^{-1}$; range 1.8-5.6), despite higher $\mathrm{pH}$ for the study lakes.

Dry deposition at the study catchments may constitute a substantial part of total deposition (Yanni et al., 2000); it was 
Table 4. Catchment-specific dry deposition factors for chloride and sulphate.

\begin{tabular}{lcc}
\hline Catchment & $\mathrm{Cl}^{-}$ & $\mathrm{SO}_{4}^{2-}$ \\
\hline Allens & 14.8 & 2.7 \\
Annis & 3.5 & 1.9 \\
Beaverskin & 2.8 & 1.4 \\
Big Dam & 3.2 & 1.5 \\
Bird & 5.3 & 2.2 \\
Branch & 3.5 & 1.2 \\
Brenton & 7.6 & 2.4 \\
Glasgow & 4.5 & 1.3 \\
Halfway & 3.2 & 1.8 \\
Huey & 2.9 & 1.9 \\
Jesse & 6.6 & 2.1 \\
John Dee & 5.2 & 1.4 \\
Little Wiles & 3.1 & 3.8 \\
Long Pond & 5.1 & 2.0 \\
Matthew & 5.8 & 2.4 \\
Mica Hill & 4.3 & 1.3 \\
Pebbleloggitch & 2.7 & 1.5 \\
Round & 4.3 & 1.4 \\
Tedford & 8.2 & 2.3 \\
Trefry & 7.8 & 2.7 \\
\hline
\end{tabular}

recently reported that dry deposition of $\mathrm{SO}_{4}{ }^{2-}$ across the region may compose up to $30 \%$ of total deposition (Jeffries and Ouimet, 2004). Catchment specific dry deposition factors (DDFs; the amount by which wet deposition must be multiplied to equal total deposition) for each major ion were calculated for each catchment because there are strong influences of catchment size, vegetation, and topography on the amount of dry deposition and the scale of the dry deposition map may be too large to capture these influences (Table 4). Lake concentrations of $\mathrm{Cl}^{-}$and $\mathrm{SO}_{4}{ }^{2-}$ were assumed to be in steady-state with respect to atmospheric inputs. Therefore, the dry deposition from the grid map was adjusted so that the sum of wet and dry depositions was equal to the runoff flux. Given the assumption that $\mathrm{Cl}^{-}$and $\mathrm{SO}_{4}{ }^{2-}$ behave conservatively, DDFs for the other ions were calculated by adjusting the marine component (if appropriate) to reflect the dry deposition of $\mathrm{Cl}^{-}$, and the non-marine component to reflect the non-marine deposition of $\mathrm{SO}_{4}{ }^{2-}$. As catchment retention of $\mathrm{SO}_{4}{ }^{2-}$ in young, poorly weathered upland soils is assumed to be very low, only a limited amount of $\mathrm{S}$ adsorption was implemented in the model (Table 3), such that $\mathrm{SO}_{4}{ }^{2-}$ behaviour is more-or-less conservative. While it has been shown that $\mathrm{SO}_{4}{ }^{2-}$ is not always conservative (Dillon and LaZerte, 1992; Yanni et al., 2000) and may be influenced by climate variations (Dillon and LaZerte, 1992), this assumption may be somewhat of a simplification in the current study. The dry deposition factors used here are somewhat higher than previous estimates have suggested for the region. Possible explana- tions include underestimation of (mapped) wet deposition, as well as unmeasured ion input from fog, which may account for a significant portion of deposition (Yanni et al., 2000). Furthermore, study of dry depositional processes in the area has been limited, and it is possible that actual dry deposition rates are higher than previous estimates have indicated. For a number of catchments (e.g. Little Wiles), dry deposition factors for $\mathrm{SO}_{4}{ }^{2-}$ are substantially higher, suggesting non-conservative behaviour, where retention of $\mathrm{SO}_{4}{ }^{2-}$ from previous years exhibits delayed release.

Model simulations were performed using an annual time step. Nitrogen uptake rates (or catchment retention) were set to equal the difference between input and output fluxes, i.e., an empirical rather than process-oriented description was specified in MAGIC. The catchments are free of any large scale anthropogenic disturbances, with eight of the catchments protected in National Parks and the remaining catchments located away from areas of development and observed to be free of harvesting. Following from this, forests in the catchments were assumed to be at steady state; thus data cataloguing biological production, removal and transformation were unnecessary. The full series of data available for water chemistry was used for model calibration. Adjustment of the initial (1850) base saturation, the aluminium solubility constant, soil DOC, and weathering rates was required for calibration. This approach allowed for a match of the exchangeable base cation fractions while simultaneously finding a best fit for water chemistry variables (Table 1). Optimal calibration for ion concentrations was ensured by evaluating the fit of the simulated to observed values using the sum of squared errors. Estimates of historic and future deposition (as described above) are required to generate hindcasts and forecasts for water chemistry during the period of interest (1850-2100).

\subsection{Critical chemical limits}

ANC (defined as the sum of base cations minus the sum of strong acid anions) and $\mathrm{pH}$ are among the most frequently used chemical criteria for characterizing aquatic ecosystem quality for biotic organisms (e.g. Dillon et al., 1987; Marmorek et al., 1996; Wright and Cosby, 2003). Following acidification, chemical recovery can be defined in two ways: return to pre-acidification conditions, or reaching some pre-determined critical chemical limit for ANC or $\mathrm{pH}$. An $\mathrm{ANC}_{\text {limit }}$ of $20 \mu \mathrm{mol}_{\mathrm{c}} \mathrm{L}^{-1}$ is often chosen as the threshold for aquatic organisms in acid-sensitive lakes (Henriksen et al., 1992; Posch et al., 1997; Whitfield et al., 2006a). Similarly, $\mathrm{pH}$ levels may be designated to protect fish or other organisms. A pH of 5.4 is generally used as the minimum level necessary to protect juvenile Atlantic Salmon (Salmo salar) (Farmer et al., 1980; Clair et al., 2004). The following discussion will focus on the priority for remediation; bringing lakes to these critical conditions wherever possible. 

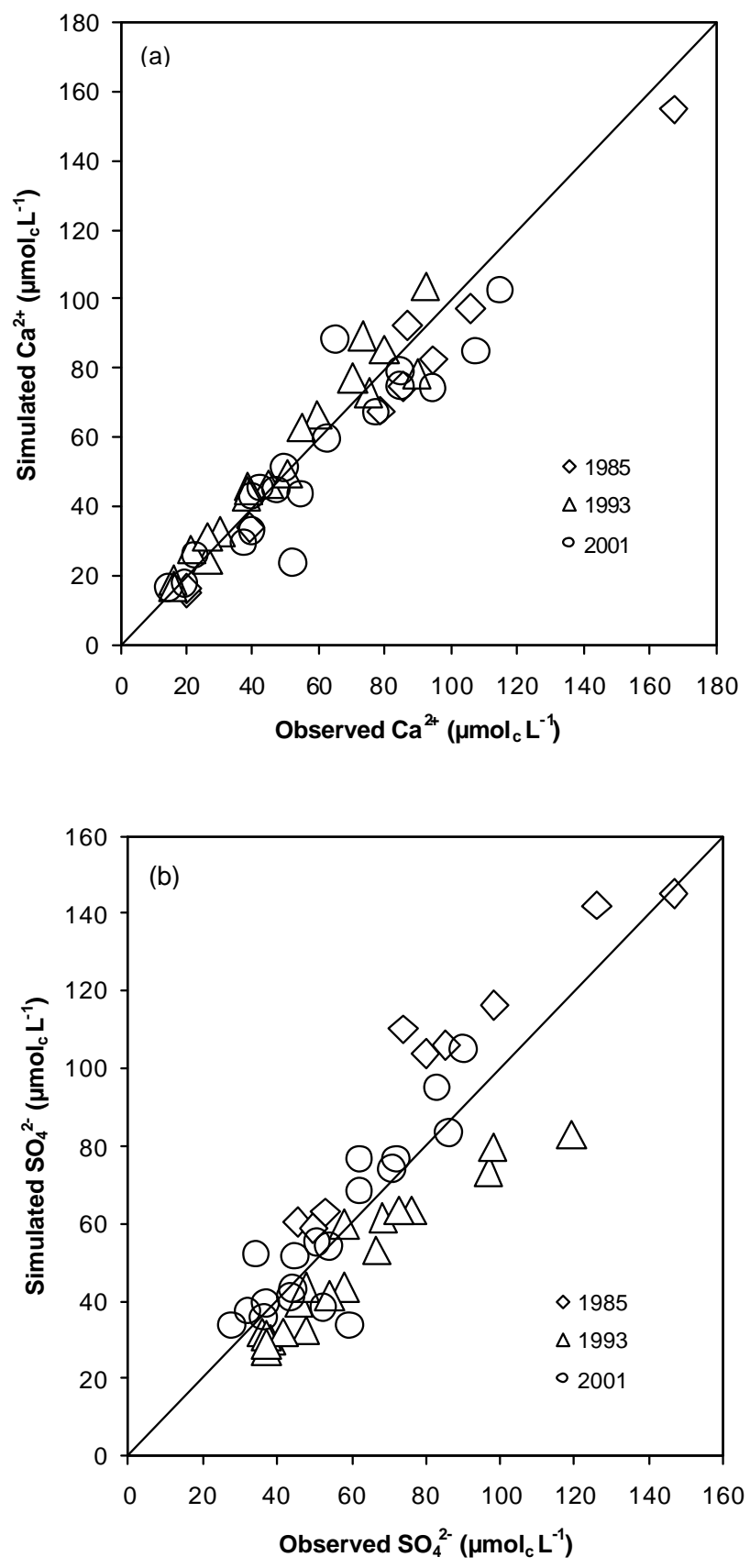

Fig. 3. Simulated vs. observed values for $\mathrm{Ca}^{2+}$ (a) and $\mathrm{SO}_{4}{ }^{2-}$ (b) lake concentrations $\left(\mu \mathrm{mol}_{\mathrm{c}} \mathrm{L}^{-1}\right)$ at the 20 study lakes for three years $(1985,1993,2001)$ spanning the calibration period.

\section{Results and discussion}

\subsection{Model calibration}

Multiple calibrations were performed on simulations run from 1850 to 2002 using the historical deposition sequences. All twenty catchments were successful calibrated. Comparison of simulated and observed values for multiple years
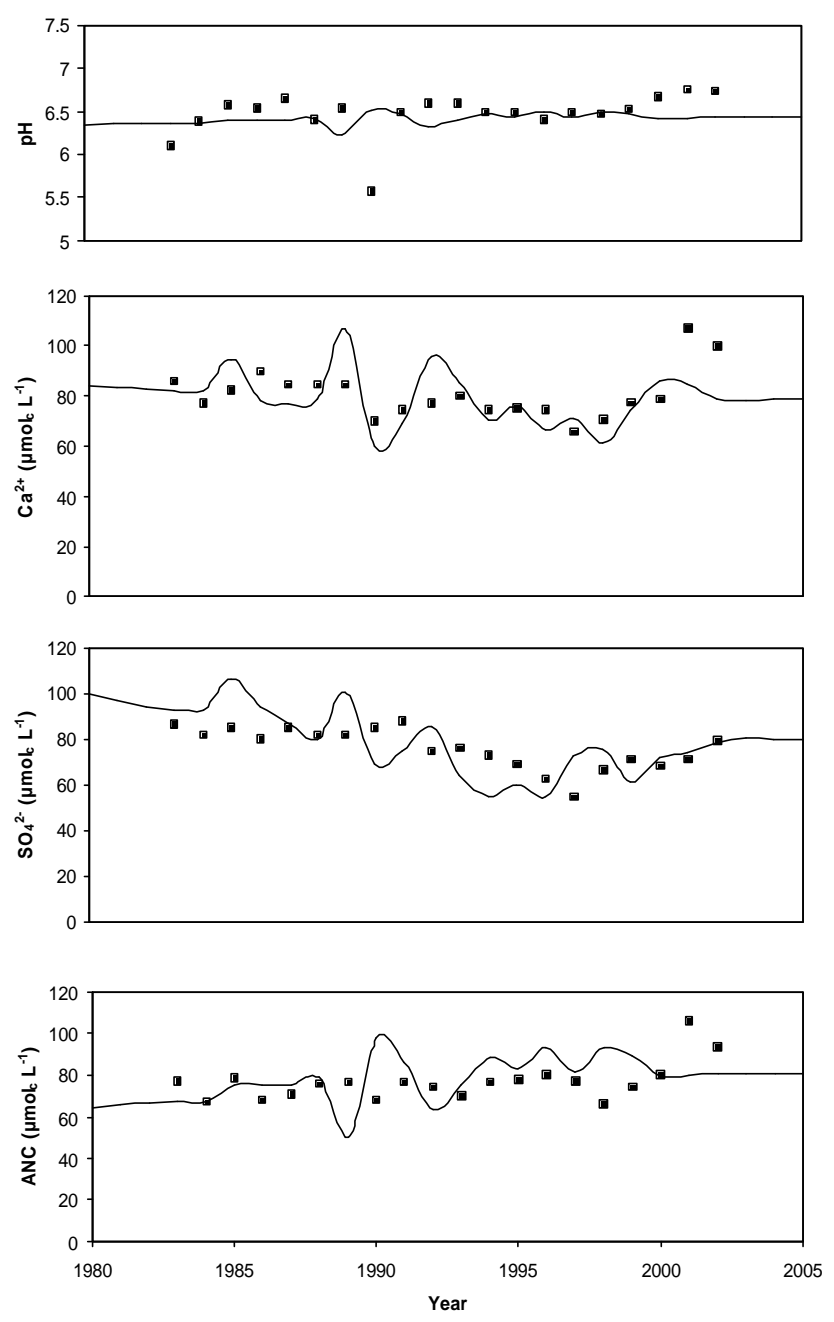

Fig. 4. MAGIC simulation (solid line) calibrated to long-term timeseries (1983-2002) of observed data (solid circles) for $\mathrm{pH}, \mathrm{Ca}^{2+}$, $\mathrm{SO}_{4}{ }^{2-}$ and ANC $\left(\mu \mathrm{mol}_{\mathrm{c}} \mathrm{L}^{-1}\right)$ at Bird Lake.

of the interactive calibration period showed good agreement (Fig. 3) with the trend through the time-series of observational data showing a good fit (Fig. 4). The normalised mean absolute error (Janssen and Heuberger, 1995) for $\mathrm{Ca}^{2+}, \mathrm{SO}_{4}{ }^{2-}$ and ANC ranged between 0.08-0.28, 0.080.29 , and $0.15-0.78$, respectively, for the time-series calibrations. In the current study, the calibration of organic acid charge density prior to input in MAGIC resulted in reasonable predictions of lake $\mathrm{pH}$ throughout the time-series used for calibration. Calibrated catchment weathering rates range from 48 to $219 \mathrm{mmol}_{\mathrm{c}} \mathrm{m}^{-2} \mathrm{yr}^{-1}$ with a mean value of $112 \mathrm{mmol}_{\mathrm{c}} \mathrm{m}^{-2} \mathrm{yr}^{-1}$ which is within the range of values previously published for the study region (Whitfield et al., 2006b). Modelled pre-industrial (1850) levels of ANC and pH suggest that 20 and 16 of the study lakes exhibit a capacity to reach the specified critical chemical criteria, respectively (Table 5). 
Table 5. Lake acid neutralizing capacity (ANC) and pH values for 1850, 1975, 2002, 2030 and 2100 as simulated by MAGIC.

\begin{tabular}{|c|c|c|c|c|c|c|c|c|c|c|}
\hline & & & ANC & & & & & $\mathrm{pH}$ & & \\
\hline Catchment & 1850 & 1975 & 2002 & 2030 & 2100 & 1850 & 1975 & 2002 & 2030 & 2100 \\
\hline Allens & 154 & 97 & 106 & 122 & 130 & 6.70 & 6.49 & 6.53 & 6.59 & 6.62 \\
\hline Bird & 125 & 60 & 81 & 92 & 98 & 6.62 & 6.31 & 6.44 & 6.49 & 6.52 \\
\hline Brenton & 126 & 37 & 83 & 88 & 94 & 5.81 & 4.47 & 4.99 & 5.09 & 5.20 \\
\hline Jesse & 103 & 44 & 76 & 79 & 82 & 6.39 & 5.82 & 6.20 & 6.23 & 6.25 \\
\hline Tedford & 98 & 35 & 70 & 73 & 76 & 6.52 & 6.08 & 6.37 & 6.39 & 6.41 \\
\hline Trefry & 158 & 85 & 119 & 126 & 131 & 6.59 & 6.20 & 6.42 & 6.46 & 6.48 \\
\hline Beaverskin & 34 & -5 & 10 & 15 & 18 & 5.96 & 4.86 & 5.35 & 5.54 & 5.60 \\
\hline Big Dam & 64 & 24 & 41 & 46 & 49 & 6.26 & 5.74 & 6.03 & 6.09 & 6.12 \\
\hline Pebbleloggitch & 43 & 4 & 19 & 25 & 27 & 4.80 & 4.41 & 4.52 & 4.58 & 4.60 \\
\hline Annis & 107 & 49 & 70 & 77 & 83 & 6.56 & 6.22 & 6.38 & 6.42 & 6.45 \\
\hline Huey & 71 & 21 & 34 & 42 & 47 & 6.22 & 5.37 & 5.73 & 5.88 & 5.96 \\
\hline Little Wiles & 77 & -29 & 1 & 21 & 30 & 6.39 & 4.52 & 5.17 & 5.79 & 5.95 \\
\hline Matthew & 89 & 51 & 55 & 57 & 59 & 6.12 & 5.51 & 5.62 & 5.65 & 5.71 \\
\hline Halfway & 63 & 20 & 33 & 39 & 42 & 6.02 & 5.01 & 5.39 & 5.57 & 5.66 \\
\hline Branch & 56 & 28 & 44 & 44 & 45 & 4.98 & 4.58 & 4.78 & 4.78 & 4.79 \\
\hline Glasgow & 38 & 12 & 27 & 28 & 29 & 5.07 & 4.60 & 4.84 & 4.86 & 4.86 \\
\hline John Dee & 72 & 41 & 59 & 59 & 60 & 5.66 & 4.91 & 5.36 & 5.37 & 5.39 \\
\hline Long & 144 & 102 & 119 & 122 & 126 & 6.69 & 6.53 & 6.60 & 6.61 & 6.63 \\
\hline Mica Hill & 79 & 46 & 64 & 66 & 67 & 5.66 & 4.89 & 5.30 & 5.35 & 5.38 \\
\hline Round & 67 & 38 & 54 & 55 & 56 & 5.21 & 4.68 & 4.94 & 4.95 & 4.97 \\
\hline
\end{tabular}

\subsection{Chemical response}

Substantial decreases in ANC and $\mathrm{pH}$ since 1850 indicate that all 20 study lakes have been impacted by acidic deposition (Table 5, Fig. 5). The time trends demonstrate a close inverse relationship with the deposition trend for $\mathrm{SO}_{4}{ }^{2-}$ (Fig. 2) where peak $\mathrm{SO}_{4}{ }^{2-}$ deposition during the 1940s and 1970 s coincide with minima of ANC and $\mathrm{pH}$. The depression of ANC and $\mathrm{pH}$ below critical limits $\left(20 \mu \mathrm{mol}_{\mathrm{c}} \mathrm{L}^{-1}\right.$ and 5.4 respectively) for extended periods of time indicates the potential for impacts on aquatic communities. Regional modelling of sensitive catchments follows similar trends in other regions in Canada (Ontario: Aherne et al., 2003), although ANC levels in for the study lakes are generally much lower. For a sub-set of the study lakes, Whitfield et al. (2006b) found that the soil profiles (rooting zone) have lower base cation weathering rates $\left(3-13 \mathrm{mmol}_{\mathrm{c}} \mathrm{m}^{-2} \mathrm{yr}^{-1}\right)$ than the profiles of sensitive soils in Ontario $\left(36-73 \mathrm{mmol}_{\mathrm{c}} \mathrm{m}^{-2} \mathrm{yr}^{-1}\right.$ : Watmough and Dillon, 2003) where the rooting zone encompasses nearly the entire soil depth. The low weathering rates (evidenced by catchment and soil profile methods) likely contribute to the low ANC levels observed for the study lakes. Similarly, the low historic ANC estimated for the Nova Scotia study lakes is due to shallow, base poor soils that exhibit low mineral weathering and have much lower pre-acidification base cation saturation (Fig. 5) when compared to sensitive regions of Ontario.
North American emissions reductions measures implemented in the 1980s are predicted to have resulted in an increase in ANC in Nova Scotian lakes. In the 1970s, nine of the lakes were predicted to have ANC below the critical limit $\left(20 \mu \mathrm{mol} \mathrm{L}^{-1}\right)$. The predicted depression in $\mathrm{pH}$ in the mid 1970 s relative to the modelled historical condition varied substantially from lake to lake; ranging from one tenth of a unit to a full unit. Recovery of ANC and $\mathrm{pH}$ started shortly after, $\mathrm{SO}_{4}{ }^{2-}$ deposition decreased in the $1970 \mathrm{~s}$, and is expected to continue slowly but steadily into the future (Fig. 5). At the end of the calibration period (2002), three lakes were below the critical ANC limit, with two of these predicted to recover to an acceptable ANC $\left(>20 \mu \mathrm{mol}_{\mathrm{c}} \mathrm{L}^{-1}\right)$ by 2030. Catchments that demonstrated the greatest buffering capacity prior to acidification have undergone the greatest absolute change in ANC, and will continue to be the most distant from their estimated natural condition upon completion of emissions reductions (Fig. 5). Ten lakes are below $\mathrm{pH}$ 5.4 in 2002, with three of these lakes predicted not to recover by the end of the forecast period (2100: Table 5), and four having a predicted low $(<5.4)$ historical $\mathrm{pH}$.

Clair et al. (2003) reported that ANC in Nova Scotia lakes will be quick to return to background levels due to the low initial ANC concentrations. The results presented here suggest otherwise, notwithstanding the relatively quick initial recovery following lower levels of acid deposition. This discrepancy may result from the inclusion of detailed soil data in this study, which may have resulted in lower estimates of 
weathering rate. By 2100 the ANC for all but one catchment is predicted to be above the critical chemical limit; however, lake ANC concentrations are predicted to be on average 19\% lower than modelled pre-acidification conditions (Table 5). The slow increase in modelled ANC concentrations likely results from a limited transfer of base cations from soils to surface waters due to the presence of small pools of base cations and low soil weathering rates (Whitfield et al., 2006b). Decreases in ANC for many lakes were not large (Table 5); yet the time trend for ANC (Fig. 5) suggests that a full recovery to pre-acidification levels would be lengthy and will be unlikely to take place without further reductions. This may further reduce the chance of the "native" biological community re-establishing itself following acidification conditions. Retention of previously deposited $\mathrm{SO}_{4}{ }^{2-}$ in the catchment and subsequent release could prolong the effects of acidification and delay further recovery (Eimers and Dillon, 2002). The assumption that $\mathrm{SO}_{4}{ }^{2-}$ demonstrates conservative behaviour is a simplification in the current study, which could result in an underestimation of recovery times where it is retained in the catchment; however, retention of $\mathrm{SO}_{4}{ }^{2-}$ may delay runoff response by only a few years (Wright and Cosby, 2003).

The increases in ANC simulated during the 1980s and 1990s are not consistent with the absence of trends in Gran alkalinity reported for the study lakes (Whitfield et al., 2006a). Evans and Monteith (2001) reported similar findings, where ANC showed increasing trends, while alkalinity did not. This inconsistency may be explained by the roles of DOC and aluminium. It is possible that organic acidity and/or aluminium influence these results, preventing detection of the trend in Gran alkalinity. Clair and Ehrman (1998) reported that DOC concentrations in the region are influenced by climate; however, Whitfield et al. (2006a) did not observe changes in DOC concentration for the study lakes using a nine year data set, and so can not explain the absence of an alkalinity trend. The estimated low charge density of DOC may be a contributing factor for the delay in recovery of alkalinity observed. DOC with low charge density may potentially contribute less alkalinity than high charge density DOC during degradation, thus alkalinity in the study lakes may be slower in responding to decreasing acid deposition than lakes with higher DOC charge density. $\mathrm{Al}^{3+}$ concentrations are not measured in the study lakes. Further investigation of these two parameters may clarify the relationship between ANC and Gran alkalinity at the study lakes.

The predicted temporal $\mathrm{pH}$ change in the study lakes can be related to their pre-industrial $\mathrm{pH}$. Lakes with a high preindustrial $\mathrm{pH}(>6.5)$ underwent less change in $\mathrm{pH}$ than lakes with a moderate pre-industrial $\mathrm{pH}$ (5.0-6.0: Fig. 5). Comparison of predicted pre-industrial $\mathrm{pH}$ and ANC (Table 5) shows that lakes with high background $\mathrm{pH}$ also had high background ANC. Lakes with high pre-industrial ANC (and $\mathrm{pH}$ ) exhibit large losses in ANC (Fig. 5), and as ANC is consumed are resistant to changes in $\mathrm{pH}$. Study lakes with
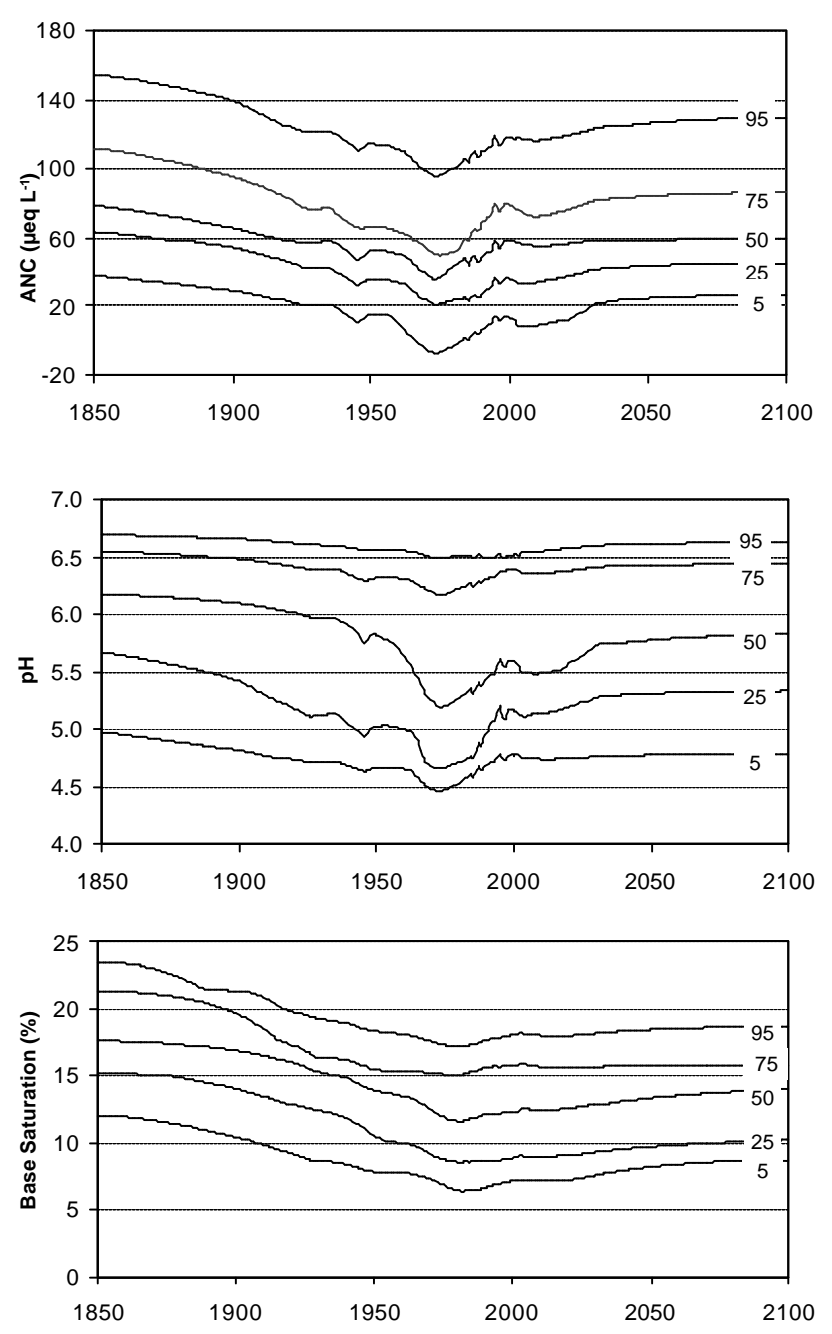

Fig. 5. Simulated percentile time-series for $\mathrm{ANC}\left(\mu \mathrm{mol}_{\mathrm{C}} \mathrm{L}^{-1}\right), \mathrm{pH}$ and soil base saturation (\%) for the period 1850-2100. The 5th, 25th, 50th, 75th and 95th percentiles are shown.

lower background $\mathrm{pH}$ are generally higher in DOC (organic acidity). Organic buffering in lakes with high DOC levels increases their resistance to anthropogenic acidification $\mathrm{pH}$ changes (Howell, 1989), and these lakes can be expected to undergo some organic buffering of incoming acid deposition. Model results show that these lakes are predicted to exhibit smaller shifts in $\mathrm{pH}$. Smaller amounts of recovery are observed at the end of the forecast, where the ANC trend levels off (Fig. 5), nonetheless forecasts suggest that lakes that had high pre-industrial $\mathrm{pH}$ will approach background levels in 2100 . Average $\mathrm{pH}$ depression is 0.23 units in 2100 , compared with 0.66 units during the peak $\mathrm{pH}$ depression during the 1970s (Table 5). 
Table 6. Target loads calculated for the four lakes predicted not to reach critical chemical limits by 2030. The target loads assume a linear decrease in $\mathrm{SO}_{4}{ }^{2-}$ deposition during the period 2002-2030.

\begin{tabular}{lcccc}
\hline Lake & Criteria & $\begin{array}{c}\text { 2030 Target Load } \\
\mathrm{mmol}_{\mathrm{c}} \mathrm{m}^{-2} \mathrm{yr}^{-1}\end{array}$ & $\begin{array}{c}\text { Non-marine } \mathrm{SO}_{4}{ }^{2-} \text { reduction } \\
\mathrm{mmol}_{\mathrm{c}} \mathrm{m}^{-2} \mathrm{yr}^{-1}\end{array}$ & $\begin{array}{c}\text { Percent reduction } \\
\% \text { non-marine } \mathrm{SO}_{4}{ }^{2-}\end{array}$ \\
\hline Brenton & $\mathrm{pH}$ & $\mathrm{N} / \mathrm{A}$ & - & - \\
John Dee & $\mathrm{pH}$ & 32.95 & 18.10 & 67 \\
Mica Hill & $\mathrm{pH}$ & 31.62 & 14.15 & 52 \\
Beaverskin & $\mathrm{ANC}$ & 24.56 & 29.46 & 77 \\
\hline
\end{tabular}

${ }^{\text {a }}$ Percent reductions are based on 2030 depositions relative to 2002 depositions for non-marine $\mathrm{SO}_{4}{ }^{2-}$.

\subsection{Target loads}

Target load analysis was performed on the four lakes (Beaverskin, Brenton, John Dee and Mica Hill) predicted to be acidified below the respective critical chemical criteria $(\mathrm{ANC} \times 1, \mathrm{pH} \times 3)$ in 2030 . Four lakes with $\mathrm{pH}<5.4$ (Pebbleloggitch, Branch, Glasgow and Round) could not be examined this way, as modelled pre-industrial values were predicted to be below the critical limit. The target load was defined as the required reduction in acid deposition to ensure lakes reach the critical chemical criteria by 2030 . It is important to note that these target loads include all expected future emissions reductions, but are more stringent in order to meet the specified chemical criteria by the target year (2030). At present, $\mathrm{N}$ does not play a significant role in acidification at the study catchments, as the majority of $\mathrm{N}$ deposition is retained in the catchments, and $\mathrm{NO}_{3}{ }^{-}$ and $\mathrm{NH}_{4}{ }^{+}$lake concentrations are at or below detection limits for all twenty lakes. Given the simplified treatment of $\mathrm{N}$ dynamics in the current study, model outputs will not be significantly affected by changes in $\mathrm{N}$ deposition. As such, the target load analysis was confined to reductions in $\mathrm{S}$ deposition. Linear reductions in acid loading were specified to begin following the end of the calibration period (2002) and to terminate in 2030. No target load calculation was possible for Brenton, indicating that only through a later evaluation year ( $>2030$ ), will it be possible to reach the critical chemical limit (Table 6). In order to restore a biologically suitable chemical condition in the remaining three lakes, target loads calculations show that a reduction of emissions to approximately $30 \%$ of present emissions levels is necessary (Table 6). Recent modelling applications for Europe (Jenkins et al., 2003; Wright et al., 2005) and Canada (Aherne et al., 2003; Environment Canada, 2004) also recommend further emissions reductions. Given that the impending effects of climate change may include increased frequency or severity of sea-salt episodes, which can be responsible for fish kills through short-term depression of ANC, it is important that critical chemical criteria continue to be evaluated in the future for their efficacy under changed environmental conditions, and if necessary adjusted to provide sufficient protection for the ecosystem. Larssen (2005) demonstrated that the severity of these sea-salt episodes will be somewhat mitigated by decreasing acid inputs.

\subsection{Base saturation}

Weathering is controlled primarily by temperature, mineralogy and water flux, and will not change significantly from year to year. Model forecasts predict that increases in ANC will slow, suggesting that the supply of base cations from the soil exchangeable pool has decreased and that base cations on the soil complex may be bound more tightly as the BS level decreases. Model hindcasts consistently predicted that BS decreased from 1850 (mean=17.7\%) through to the mid1980 's (mean $=11.9 \%$ ), approximately 10 years after peak $\mathrm{SO}_{4}{ }^{2-}$ deposition, and 10 years after minima for ANC and $\mathrm{pH}$ were predicted. This suggests that base cation release from the soil may have decreased after recovery in surface water chemistry began and is a possible explanation for the limited recovery observed in surface waters. In soils where BS has decreased due to acidic deposition (base cation outputs exceed inputs), $S$ reductions are necessary to increase BS (Jenkins et al., 2003). Recovery is consistently simulated across the study catchments throughout the 100 year forecast, but by 2100 only a small fraction of the base cations lost to acidification have been restored (Fig. 5). Simulation results for soils at acid-sensitive catchments in central Ontario continue to show long-term decreases in BS under proposed emission reduction scenarios (Aherne et al., 2003), which may be in part attributed to higher current deposition in that region. Nonetheless, soils in Nova Scotia are depleted in base cations and the relatively small soil pools (Whitfield et al., 2006b) provide little contribution of base cations to runoff, resulting in very sensitive surface waters.

Predicted increases in BS were largest during the period from 2030-2050, relative to 2010-2030, 2050-2070. This BS restoration process appears to indicate that a new equilibrium between the soil solution and exchangeable sites is being established corresponding to the level of deposition for 2030. As the BS decreases, base cations may become harder to displace from, and easier to return to, the exchange- 
able sites on the soil. This should allow for a relatively quick equilibration to new (lower) levels of deposition as base cations return to soil exchange complexes. Simulations indicate that the catchment soils lost an average of $32 \%$ of their estimated pre-industrial exchangeable base cations by the mid 1980s, when base saturation was at a minimum. The end of the forecast period shows an average loss of $23 \%$ of pre-industrial base saturation (Fig. 5). In comparison to the recovery in lake ANC and $\mathrm{pH}$ described above, restoration of soil pools is a much slower process. Larssen (2005) reported that soil pools of exchangeable base cations for Norwegian catchments required several hundred years for recovery. It appears the soils in Nova Scotia, with their low weathering rates (48-219 $\mathrm{mmol}_{\mathrm{c}} \mathrm{m}^{-2} \mathrm{yr}^{-1}$ ) will too require a long period for recovery under proposed emissions scenarios. Given the relatively low weathering rates in the study catchments, further reductions in acidic deposition are needed to widen the margin between inputs of base cations from atmospheric deposition and weathering, and the outputs in runoff stimulated by acidic deposition in order to expedite the return of base saturation levels towards their pre-acidification levels. Furthermore, it appears that ANC and $\mathrm{pH}$ will see only limited improvements without increases in BS and base cation pools to a level closer to their pre-acidification state. This may have important consequences for the biological communities in the lakes.

\section{Conclusions}

The application of MAGIC to twenty headwater catchments in Nova Scotia was used to determine the extent of acidification in the region, as well as the potential for recovery. An ANC of $20 \mu \mathrm{mol}_{\mathrm{c}} \mathrm{L}^{-1}$ and $\mathrm{pH}$ of 5.4 were defined as critical chemical limits for aquatic organisms in the current study. Four lakes were predicted to have pre-industrial (1850) values less than $\mathrm{pH}$ 5.4. Under the proposed emissions reductions (to approximately $50 \%$ of current deposition) only four of the remaining catchment were predicted to remain below the critical chemical limits. However, three of the four lakes were further predicted to reach the chemical criteria by 2030 under more stringent emissions reductions (to approximately $30 \%$ of current deposition). In contrast to the generally good prognosis for surface waters, soils base saturation recovery was predicted to be very slow, averaging $23 \%$ lower than pre-acidification levels in 2100 . As soils reach a new equilibrium with deposition following completion of emissions reductions, the rate of improvement of water chemistry is expected to taper. Additional emissions reductions are necessary to allow soils and surface waters to reach acceptable chemical criteria and to reverse some of the damage from anthropogenic acidification.

Acknowledgements. This work was funded by a NSERC Strategic Grant awarded to P. J. Dillon (Trent University), J. Smol and B. Cumming (Queen's University). Tom Clair's support with the water quality data and knowledge of the study area was greatly appreciated. We thank all individuals who contributed to sample collection and lab analysis of the soil and water samples used in this research. The authors gratefully acknowledge the Canadian National Atmospheric Chemistry (NAtChem) Precipitation Database and its data contributing agencies for the provision of the wet deposition maps for 1994-1998, used in this publication. The agencies responsible for data contributions in 2002 to the NAtChem/Precipitation Database include Environment Canada, the provinces of New Brunswick, Nova Scotia and Newfoundland.

Edited by: K. Bishop

\section{References}

Aherne, J., Dillon, P. J., and Cosby, B. J.: Acidification and recovery of aquatic ecosystems in south central Ontario, Canada: regional application of the MAGIC model, Hydrol. Earth Syst. Sci., 7, 561-573, 2003,

http://www.hydrol-earth-syst-sci.net/7/561/2003/.

Aherne, J. and Farrell, E. P.: Deposition of sulphur, nitrogen and acidity in precipitation over Ireland: chemistry, spatial variation and long-term trends, Atmos. Environ., 36, 8, 1379-1389, 2002.

Beamish, R. J. and Harvey, H. H.: Acidification of the La Cloche Mountain lakes, Ontario and resulting fish mortalities, Journal of the Fisheries Research Board of Canada, 29, 1131-1143, 1972.

Clair, T. A., Dennis, I. F., Amiro, P. G., and Cosby B. J.: Past and future chemistry changes in acidified Nova Scotian Atlantic salmon (Salmo salar) rivers: a dynamic modeling approach, Canadian Journal of Fisheries and Aquatic Sciences, 61, 1965-1975, 2004.

Clair, T. A., Dennis, I. F., and Cosby, B. J.: Probable changes in lake chemistry in Canada's Atlantic Provinces under proposed North American emission reductions, Hydro. Earth Syst. Sci., 7, 574-583, 2003.

Clair, T. A., Ehrman, J. M., Ouellet, A. J., Brun, G., Lockerbie, D., and Ro, C. U.: Changes in freshwater acidification trends in Canada's Atlantic Provinces: 1983-1997, Water, Air, and Soil Pollution, 135, 335-354, 2002.

Clair, T. A., Lockerbie, D., and Ouellet, A. J.: Environment Canada's Precipitation Monitoring Networks in Atlantic Canada, CD-ROM Atlantic Region Report - Occasional Report No. 16, Environment Canada, Sackville, New Brunswick, 2001.

Clair, T. A. and Ehrman, J. M.: The influence of changing seasonal climates in modifying discharge, dissolved organic carbon and nitrogen export in wetland influenced rivers: a neural network approach, Water Resour. Res., 34, 447-455, 1998.

Cosby, B. J., Ferrier, R. C., Jenkins, A., and Wright, R. F.: Modelling the effects of acid deposition: refinements, adjustments and inclusion of nitrogen dynamics in the MAGIC model, Hydrol. Earth Syst. Sci., 5, 499-517, 2001, http://www.hydrol-earth-syst-sci.net/5/499/2001/.

Cosby, B. J., Norton, S. A., and Kahl, J. S.: Using a pairedcatchment manipulation experiment to evaluate a catchmentscale biogeochemical model, The Science of the Total Environment, 183, 49-66, 1996.

Cosby, B. J., Hornberger, G. M., Galloway, J. N., and Wright, R. F.: Modeling the Effects of Acid Deposition: Assessment of a Lumped Parameter Model of Soil Water and Streamwater Chemistry, Water Resour. Res., 21, 51-63, 1985a. 
Cosby, B. J., Hornberger, G. M., Galloway, J. N., and Wright, R. F.: Time scales of catchment acidification, Environ. Sci. Technol., 19, 1144-1149, 1985b.

Dillon, P. J., Somers, K. M., Findeis, J., and Eimers, M. C.: Coherent response of lakes in Ontario, Canada to reductions in sulphur deposition: the effects of climate on sulphate concentrations, Hydrol. Earth Syst. Sci., 7, 583-595, 2003,

http://www.hydrol-earth-syst-sci.net/7/583/2003/.

Dillon, P. J. and LaZerte, B. D.: Response of the Plastic Lake catchment, Ontario, to reduced sulphur deposition, Environ. Pollut., 77, 211-217, 1992.

Dillon, P. J., Lusis, M., Reid, R., and Yap, D.: Ten-year trends in sulphate, nitrate and hydrogen deposition in central Ontario, Atmos. Environ., 22, 901-905, 1988.

Dillon, P. J., Reid, R. A., and de Grosbois, E.: The rate of acidification of aquatic ecosystems in Ontario, Canada, Nature, 329, 45-48, 1987.

Dillon, P. J., Jeffries, D. S., Snyder, W., Reid, R., Yan, N. D., Evans, D., Moss, J., and Scheider, W. A.: Acidic Precipitation in SouthCentral Ontario: Recent Observations, Journal of the Fisheries Research Board of Canada, 35, 809-815, 1978.

Driscoll, C. T., Lehtinen, M. D., and Sullivan, T. J.: Modeling the acid-base chemistry of organic solutes in Adirondack, New York, lakes, Water Resour. Res., 30, 297-306, 1994.

Eimers, M. C. and Dillon, P. J.: Climate effects on sulphate flux from forested catchments in south-central Ontario, Biogeochemistry, 61, 337-355, 2002.

Environment Canada: Hydrological Atlas of Canada, Canadian National Committee for the International Hydrological Decade, Ottawa, Ontario, 1978.

Environment Canada: Canadian National Atmospheric Chemistry Precipitation Database, Meteorological Service of Canada, 4905 Dufferin Street, Toronto, Canada, 2003.

Environment Canada: Canadian Acid Deposition Science Assessment: Summary of Key Results, Environment Canada, Meteorological Service of Canada, Downsview, Ontario, 2004.

Evans, C. D. and Monteith, D. T.: Chemical trends at lakes and streams in the UK Acid Waters Monitoring Network, 19882000: Evidence for recent recovery at a national scale, Hydrol. Earth Syst. Sci., 5, 351-366, 2001, http://www.hydrol-earth-syst-sci.net/5/351/2001/.

Farmer, G. J., Goff, T. R., Ashfield, D., and Samant, H. F.: Some effects of the acidification of Atlantic salmon rivers in Nova Scotia, Canadian Technical Report of Fisheries and Aquatic Sciences, 972, 1-13, 1980.

Galloway, J. N., Dianwu, Z., Thomson, V. E., and Chang, L. H.: Nitrogen mobilisation in the United States of America and the People's Republic of China, Atmos. Environ., 30, 1551-1661, 1996.

Galloway, J. N.: Acid deposition: perspectives in time and space, Water, Air, and Soil Pollution, 85, 15-24, 1995.

Gorham, E.: The chemical composition of lake waters in Halifax County, Nova Scotia, Limnol. Oceanogr., 2, 12-21, 1957.

Hedin, L., Granat, L., Likens, G. E., Buishand, T. A., Galloway, J. N., Butler, T. J., and Rodhe, H.: Steep declines in atmospheric base cations in regions of Europe and North America, Nature, 367, 351-354, 1994.

Henriksen, A., Kamari, J., Posch, M., and Wilander, A.: Critical loads of acidity: Nordic surface waters, Ambio, 21, 356-363,
1992.

Howell, G. D.: Seasonal patterns of mineral and organic acidification in two streams in southwestern Nova Scotia, Water, Air, and Soil Pollution, 46, 165-175, 1989.

Hruska, J., Kohler, S., Laudon, H., and Bishop, K. Is a Universal Model of Organic Acidity Possible: Comparison of the Acid Base Properties of Dissolved Organic Carbon in the Boreal and Temperate Zones, Environ. Sci. Technol., 37, 1726-1730, 2003.

Husar, R.: Industrial Metabolism: Sulphur and Nitrogen Emission Trends for the United States: An Application of the Materials Flow Approach, United Nations University Press, 1994.

Janssen, P. H. M. and Heuberger, P. S. C.: Calibration of processoriented models, Ecological Modelling, 83, 55-66, 1995.

Jeffries, D. S., Clair, T. A., Couture, S., Dillon, P. J., Dupont, J., Keller, W., McNicol, D. K., Turner, M. A., Vet, R., and Weeber, R.: Assessing the Recovery of Lakes in Southeastern Canada from the Effects of Acidic Deposition, Ambio, 32, 176-182, 2003.

Jeffries, D. S. and Ouimet, R.: Canadian Acid Deposition Science Assessment Chapter 8: Critical Loads: Are They Being Exceeded?, Meteorological Service of Canada, Environment Canada, Downsview, Ontario, 2004.

Jenkins, A., Camarero, L., Cosby, B. J., Ferrier, R. C., Forsius, M., Helliwell, R. C., Kopacek, J., Majer, V., Moldan, F., Posch, M., Rogora, M., Schopp, W., and Wright, R. F.: A modelling assessment of acidification and recovery of European surface waters, Hydrol. Earth Syst. Sci., 7, 447-455, 2003, http://www.hydrol-earth-syst-sci.net/7/447/2003/.

Kaminski, J. W.: Emissions-Scenario Simulations of New Provincial $\mathrm{SO}_{2}$ Reduction Targets using the Acid Deposition and Oxidant Model, Atmospheric Research and Modelling Consultants, Toronto, Canada, 2002.

Larssen, T., Brereton, C., and Gunn, J. M.: Dynamic modelling of recovery from acidification of lakes in Killarney Park, Ontario, Canada, Ambio, 32, 244-248, 2003.

Larssen, T.: Model prognoses for future acidification recovery of surface waters in Norway using long-term monitoring data, Environ. Sci. Technol., 39, 7970-7979, 2005.

Marmorek, D. R., MacQueen, R. M., Wedeles, C. H. R., Korman, J., Blancher, P. J., and McNicol, D. K.: Improving $\mathrm{pH}$ and alkalinity estimates for regional-scale acidification models: incorporation of dissolved organic carbon, Canadian Journal of Fisheries and Aquatic Sciences, 53, 1602-1608, 1996.

Office of Technology Assessment: Acid rain and transported air pollutants: Implications for public policy, OT A-0-204, U.S. Congress Office of Technology Assessment, Washington, D.C., 1984.

Posch, M., Kamari, J., Forsius, M., Henriksen, A., and Wilander, A.: Environmental auditing: Exceedance of Critical Loads for Lakes in Finland, Norway, and Sweden: Reduction Requirements for Acidifying Nitrogen and Sulfur Deposition, Environ. Manage., 21, 291-304, 1997.

Ro, C. U. and Vet, R. J.: Analyzed data fields from the National Atmospheric Chemistry Database (NAtChem) and Analysis Facility, Air Quality Research Branch, Meteorological Service of Canada, Environment Canada, Toronto, 2003.

Shaw, R. W.: Acid precipitation in Atlantic Canada, Environ. Sci. Technol., 13, 406-411, 1979.

UNECE: Manual on methodologies and criteria for Modelling and 
Mapping Critical Loads and Levels and Air Pollution Effects, Risks, Trends, Pages V.-13, in: Convention on Long-range Transboundary Air Pollution, 2004.

U.S. EPA: National Air Pollutant Emissions Trends, 1900-1998, EPA-454/R-00-002, United States Environmental Protection Agency Office of Air Quality Planning and Standards Research, Triangle Park, 2000.

Vet R. J. and Shaw, M.: 1994-1998 average dry deposition velocities calculated using the MSC Air Quality Research Branch dry deposition model (RDM), Meteorological Service of Canada, Environment Canada, Toronto, Ontario, 2004.

Watmough, S. A. and Dillon, P. J.: Base cation and nitrogen budgets for seven forested catchments in central Ontario, Forest Ecol. Manage., 177, 155-177, 2003.

Whitfield, C. J., Aherne, J., Watmough, S. A., Dillon, P. D., and Clair, T. A.: Recovery from acidification in Nova Scotia: temporal trends and critical loads for 20 headwater lakes, Canadian Journal of Fisheries and Aquatic Sciences, 63, 1504-1514, 2006a.
Whitfield, C. J., Watmough, S. A., Aherne, J., and Dillon, P. D.: A comparison of weathering rates for acid-sensitive catchments in Nova Scotia, Canada and their impact on critical load calculations, Geoderma, 136, 899-911, 2006b.

Wright, R. F., Larssen, T., Camarero, L., Cosby, B. J., Ferrier, R. C., Helliwell, R. C., Forsius, M., Jenkins, A., Kopacek, J., Majer, V., Moldan, F., Posch, M., Rogora, M., and Schopp, W.: Recovery of acidified European surface waters, Environ. Sci. Technol., 39, 64A-72A, 2005.

Wright, R. F. and Cosby, B. J.: Future recovery of acidified lakes in southern Norway predicted by the MAGIC model, Hydrol. Earth Syst. Sci., 7, 467-483, 2003, http://www.hydrol-earth-syst-sci.net/7/467/2003/.

WxPrime Corporation: Emissions-scenario simulations of potential nitrogen emission reductions using the Acid Deposition and Oxidant Model (ADOM), Report prepared for Meteorological Service of Canada, Toronto, Ontario, 51p., 2004.

Yanni, S., Keys, K., Clair, T. A., and Arp, P. A.: Fog and acidification impacts on ion budgets of basins in Nova Scotia, Canada, J. Amer. Water Resour. Assoc., 36, 619-631, 2000. 